\title{
The structure of employment of pensioners in China in the context of reforming the pension system
}

\author{
You Min¹, I. Yu. Kiselev ${ }^{1}$
}

1P. G. Demidov Yaroslavl State University, 14 Sovetskaya str., Yaroslavl 150003, Russian Federation

DOI: $10.18255 / 2412-6519-2021-3-286-305$

Research Article

Full text in Russian

In the article the results of sociological research, directed to the study of pensioners' employment structure in China under the situation of pension system's reformation and gradual increase of retirement age, are presented. It is demonstrated that the level of pensioners' employment in China remains relatively low. The major incentives to continue labor activities are of economic origin and deal with the low pension and desire to have savings for the future.

Low wages and unfavorable terms of work are becoming the main barriers to employment of working pensioners. As the reason for their unemployment the non-working pensioners name the absence of vacancies, corresponding to their qualifications. It is established that the further labor activities for almost half of the pensioners is accompanied by a change of place of work and / or profession. There is an outflow of pensioners from such spheres of employment as power structures (army, security agencies), government bodies, finance and insurance, and industry. Agriculture is becoming the "accepting" industry for pensioners. After retirement, the number of employees in state-owned enterprises is reduced. Simultaneously, there is an increase in the share of pensioners in private enterprises; they become entrepreneurs or the self-employed. At the same time, pensioners are often employed in low-skilled labor. In this regard, the reform of China's pension system, including raising the retirement age, should be accompanied by the development of measures to promote the employment of the elderly, taking into account both quantitative and qualitative aspects. Among them are: the subsidizing employment for pensioners, promoting the education of the elderly, developing measures for additional social support for working pensioners.

Keywords: employment; raising the retirement age; pensioners; motives for labor activities; working conditions; China

INFORMATION ABOUT THE AUTHORS

$$
\begin{array}{r|l}
\text { You, Min } & \begin{array}{l}
\text { E-mail: 261747567@qq.com } \\
\text { Graduate student }
\end{array} \\
\begin{array}{r|r}
\text { Kiselev, Igor Y. } \\
\text { (correspondence author) }
\end{array} & \begin{array}{l}
\text { E-mail: igkisselev@mail.ru } \\
\text { Doc. Sc. (Sociology), Professor, Head of the department } \\
\text { of sociology }
\end{array}
\end{array}
$$

For citation: Min You, Kiselev I. Y. The structure of employment of pensioners in China in the context of reforming the pension system // Social'nye i gumanitarnye znanija. 2021. Vol. 7, No 3. P. 286-305. (in Russ.)

(C) Min You, Kiselev I. Y., 2021

This is an open access article under the CC BY license (https://creativecommons.org/licenses/by/4.0/) 


\title{
Структура занятости пенсионеров Китая в условиях реформирования пенсионной системы
}

\author{
Ю Минь ${ }^{1}$, И. Ю. Киселев ${ }^{1}$
}

1Ярославский государственный университет им. П.Г. Демидова, ул. Советская, 14, Ярославль, 150003, Российская Федерация

DOI: $10.18255 / 2412-6519-2021-3-286-305$

УдК 316.334.22, 316.346.32-053.9

Научная статья Полный текст на русском языке

В статье представлены результаты социологического исследования, направленного на изучение структуры занятости пенсионеров Китая в условиях реформирования пенсионной системы, в том числе постепенного повышения пенсионного возраста. Показано, что уровень занятости пенсионеров в Китае остается достаточно низким. Основные мотивы продолжения трудовой деятельности пенсионеров имеют экономический характер и связаны с низким размером пенсии и желанием сделать сбережения на будущее. Низкий размер оплаты труда и невыгодные условия найма становятся главными барьерами занятости работающих пенсионеров. Неработающие пенсионеры в качестве причины незанятости называют отсутствие вакансий, соответствующих их квалификации. Установлено, что продолжение трудовой деятельности почти для половины пенсионеров сопровождается сменой места работы и/или профессии. Наблюдается отток пенсионеров из таких сфер занятости, как силовые структуры (армия, органы безопасности), органы управления, финансы и страхование, промышленность. «Принимающей» отраслью для пенсионеров становится сельское хозяйство. После выхода на пенсию сокращается количество занятых на государственных предприятиях. Одновременно наблюдается увеличение доли пенсионеров на частных предприятиях, занятых предпринимательской деятельностью, самозанятых. При этом пенсионеры зачастую заняты низкоквалифицированным трудом. В связи с этим реформирование пенсионной системы Китая, в том числе повышение пенсионного возраста, должно сопровождаться разработкой мер содействия занятости пожилых с учетом как количественных, так и качественных аспектов. Среди них: субсидирование занятости для пенсионеров, содействие образованию пожилых людей, разработка мер дополнительной социальной поддержки работающих пенсионеров.

Ключевые слова: занятость; повышение пенсионного возраста; пенсионеры; мотивы трудовой деятельности; условия трудовой деятельности; Китай

ИНФОРМАЦИЯ ОБ АВТОРАХ

$$
\begin{aligned}
& \text { Минь, Ю | E-mail: 261747567@qq.com } \\
& \text { Аспирант кафедры социологии }
\end{aligned}
$$
Киселев, Игорь Юрьевич
E-mail: igkisselev@mail.ru
(автор для корреспонденции)
Доктор социологических наук, профессор, заведующий кафедрой социологии

Для цитирования: Минь Ю, Киселев И. Ю. Структура занятости пенсионеров Китая в условиях реформирования пенсионной системы // Социальные и гуманитарные знания. 2021. Том 7, № 3 . C. 286-305.

(С) Минь Ю, Киселев И. Ю., 2021

Статья открытого доступа под лицензией СС BY (https://creativecommons.org/licenses/by/4.0/) 
В статье представлены результаты социологического исследования, направленного на изучение структуры занятости пенсионеров Китая.

Актуальность исследования определяется особенностями социально-демографической ситуации в Китае, характеристиками пенсионной системы в этой стране, состоянием рынка труда и положением пенсионеров в его структуре.

Влияние первого фактора связано с тем, что Китай, начиная со второй половины XX века, переживает демографические изменения, связанные с ростом численности пожилого населения. Согласно данным ООН, к 2050 году Китай войдет в число стран, в которых доля населения старше 65 лет составит свыше 15 \% [1, с. 9].

Старение населения стало следствием проведения демографической политики «одна семья - один ребенок». В результате в Китае получила распространение модель семьи «4-2-1», в которой один ребенок, став взрослым, вынужден заботиться о двух своих родителях и четырех бабушках и дедушках [2, с. 27]. Подобная структура семьи оказывает долгосрочное влияние на развитие рынка труда и систему социального обеспечения. Так, меняется соотношение количества пенсионеров и работающих жителей Китая. Если в 1978 году на 1 пенсионера приходилось 30 работающих, то в 2001 году подобное соотношение составляло 1:3,5, а к 2050 году прогнозируется соотношение - 1:1,69 [Там же. С. 24]. В результате Китай стал одной из стран с самым высоким уровнем занятости - 80 \% [3, с. 1]. Как мужчины, так и женщины работают большую часть взрослой жизни.

Сложившаяся в результате демографической политики структура семьи привела к переосмыслению функции семьи как института заботы о пожилых. Учитывая возросшую нагрузку на работающих членов семьи, данный институт не способен нести бремя заботы о пожилых родственниках. Как следствие, подобную функцию должно взять на себя государство посредством развития системы пенсионного обеспечения.

Однако сложившаяся в настоящий момент пенсионная система Китая не способна в полной мере выполнить функцию социального обеспечения растущего пожилого населения страны. В качестве «слабых мест» пенсионной системы эксперты называют недоступность пенсий для сельского населения, привязку пенсионного обеспечения к системе прописки, существование отличающихся пенсионных планов для разных категорий населения [4, с. 51-52]. Пенсия по старости в Китае остается довольно маленькой и не соответствует уровню экономического развития страны. Кроме того, в Китае сохраняется низкий возраст выхода на пенсию: 45-60 лет в зависимости от пола, состояния здоровья, сектора экономики и профессии. Отмеченные особенности системы пенсионного обеспечения не способствуют снижению демографической нагрузки на работающее население.

В результате эксперты говорят о необходимости реформирования пенсионной системы Китая [4]. В частности, власти Китая объявили о постепенном повышении пенсионного возраста в период с 2021 по 2025 годы [5].

Реформирование пенсионной системы, в том числе повышение пенсионного возраста, требует оценки последствий подобных изменений для рынка труда. Для этого, в свою очередь, необходимо проанализировать существующую структуру занятости пенсионеров Китая. Данная проблематика не получила систематического изучения: имеются лишь отдельные примеры исследований, проведенных в разные годы [3; 6, с. 89-108]. 
В связи с этим задачи социологического исследования структуры занятости пенсионеров Китая состоят в следующем:

1) выявить социально-демографические характеристики работающих пенсионеров;

2) установить мотивы продолжения трудовой деятельности;

3) описать условия занятости пенсионеров;

4) выявить субъективно определяемые барьеры занятости пенсионеров;

5) описать структуру доходов работающих пенсионеров.

\section{Положение пенсионеров на рынке труда: социально-экономический контекст}

Согласно результатам социологического лонгитюдного исследования старения в Китае (CLASS), полученным в марте 2016 г., 85,9 \% пожилых людей охвачены системой пенсионного страхования. При этом доля мужчин, получающих пенсии, составляла 89,08 \%, доля женщин - 82,76 \%. Существует неравенство в сфере пенсионного обеспечения городского и сельского населения. Так, доля пожилого городского населения, получающего пенсии, составляет 91,25 \%, в то время как доля пожилых сельских жителей - 70,79\% [7, с. 22].

Вследствие неравномерного распределения пенсионных выплат они чаще всего не рассматриваются китайцами в качестве основного источника дохода после выхода на пенсию. Согласно результатам исследования CLASS 2016 г., китайские пенсионеры называли три основные источника дохода: собственная пенсия $(46,18 \%)$, помощь детей $(21,68$ \%) и доход от трудовой деятельности $(16,12 \%)$. При этом доля пожилых, полагающихся на свои пенсии как источник дохода, в городах выше, чем в сельской местности: 71,90 \% и 17,22 \% соответственно. Для сельских жителей основной источник дохода - это помощь детей и трудовой доход [Там же. С. 20].

Таким образом, неравномерность распределения пенсий, уровень пенсионных выплат, не позволяющий рассматривать их как основной источник дохода, могут мотивировать пенсионеров на продолжение трудовой деятельности.

Вместе с тем анализ положения пенсионеров на рынке труда Китая не позволяет сделать однозначный вывод в пользу данного утверждения.

Ситуация в сфере занятости в Китае достаточно противоречива. Так, Ли Чунлинг со ссылкой на результаты китайского социального исследования (CSS) 2013 г., проведенного Институтом социологии Китайской академии общественных наук (ИС КАОН), отмечает, что уровень незанятости среди представителей старшего возраста (51-60 лет) довольно высок и составляет 26,3 \%. При этом лишь 2,1 \% пенсионеров хотели бы работать и $1,4 \%$ - ищут работу [6, с. 93].

Согласно результатам социологического лонгитюдного исследования старения в Китае (CLASS), полученным в марте 2016 г., 19,25 \% пожилых людей продолжают работать. При этом уровень занятости среди пожилых мужчин выше, чем среди женщин: 23,33 \% и 15,32 \% соответственно. Кроме того, наблюдаются очевидные различия в уровне занятости пожилых людей, живущих в городах и сельской местности. Так, доля работающих пожилых людей в городах составляет 10 \%, а доля работающих пожилых людей в сельских районах составляет 29,67 \%. С увеличением возраста доля работающего пожилого населения снижается. Чаще всего работают 
пожилые люди в возрасте 60-64 лет, то есть 5-10 лет (в зависимости от пола) ${ }^{1}$ после выхода на пенсию. После 75 лет количество работающих пожилых людей резко сокращается. Вместе с тем доля пожилых людей в возрасте до 80 лет, продолжающих трудовую деятельность, среди сельских жителей выше, чем в городе [7, с. 25-26]. С одной стороны, это может быть связано с тем, что в сельской местности нет обязательного пенсионного возраста. Пока пожилые люди здоровы, они продолжают работать. С другой стороны, необходимость продолжения трудовой деятельности в пожилом возрасте обусловлена низким уровнем жизни и социальной защищенности данной категории граждан Китая.

Анализ профессий работающих пожилых людей отражает отмеченные выше различия в занятости городских и сельских пенсионеров. Согласно результатам социологического лонгитюдного исследования старения в Китае (CLASS), полученным в марте 2016 г., пожилые люди заняты ${ }^{2}$ прежде всего в сельском хозяйстве, животноводстве, рыболовстве. Они работают как фрилансеры, трудятся в качестве профессионального технического персонала, разнорабочих в торговле, в сфере обслуживания и производства. Реже всего пожилые работают на должности управленцев разного уровня [Там же. С. 26].

Завершая краткий обзор, можно сделать вывод, что существование разных пенсионных планов, зависимость размера пенсии от проживания в городе или на селе мотивируют пенсионеров на продолжение трудовой деятельности. В то же время процент работающих пенсионеров невысок. С чем это связано - с низкой мотивацией трудовой деятельности, обусловленной достаточностью пенсии для самообеспечения, или невозможностью найти работу? На эти вопросы необходимо ответить в ходе проводимого социологического исследования.

\section{Методика исследования}

С целью изучения структуры занятости пенсионеров Китая в период с 13.01.2021 по 04.02.2021 проведено социологическое исследование методом анкетирования. В качестве респондентов выступили жители Китая, которые относят себя к категории пенсионеров.

В исследовании применена квотная выборка. Квоты заданы, во-первых, в зависимости от места жительства респондента в одном из четыре регионов Китая (восточный, северо-восточный, западный, центральный). Во-вторых, установлены квоты для жителей провинций, которые относятся к каждому из регионов Китая 3 .

Всего опрошено 400 респондентов: 29,3 \% - мужчины и 70,7 \% - женщины. Распределение респондентов по возрасту следующее: 50-54 года - 19,5 \%; 55-59 лет - 25,8 \%; 60-64 года - 30 \%; 65-69 лет - 16,5 \%; 70 лет и старше - 8,3 \%.

\footnotetext{
${ }^{1}$ В Китае установленный законом пенсионный возраст составляет 55 лет для женщин и 60 лет для мужчин. ${ }^{2}$ В порядке снижения частоты.

${ }^{3}$ Для расчета квот применялись данные о численности населения в провинциях по данным Национального статистического бюро Китая: http://www.stats.gov.cn/tjsj/ndsj/2020/indexch.htm
} 
В исследовании приняли участие респонденты с разным уровнем образования: с начальным и неполным средним - 32,5 \%; средним и средним специальным 40,8 \%; высшим - 26,8 \%.

Участники социологического исследования живут в мегаполисах ${ }^{1}-8,8$ \%; столицах провинций ${ }^{2}-34,5 \%$; городах окружного значения ${ }^{3}-22 \%$, уездных городах - 19,3\%; селах ${ }^{5}-15,5 \%$.

Большинство респондентов проживает вместе с супругами $(40,3 \%)$ или с супругами и детьми (33,8 \%); 10,5 \% - с детьми; 2,3 \% - с внуками; 1,5 \% - с другими родственниками; $11,8 \%$ - одиноки.

Эмпирическую базу исследования составили также данные анкетирования пенсионеров, проведенного в рамках того же временного периода в двух регионах Китая - северо-восточном ${ }^{6}(\mathrm{n}=1190)$ и восточном ${ }^{7}(\mathrm{n}=517)$ - с целью выявления региональной специфики структуры занятости пенсионеров.

Для сбора первичных эмпирических данных применялась анкета, содержащая следующие смысловые блоки для работающих и неработающих пенсионеров. Неработающим пенсионерам были заданы вопросы о том, работали ли они раньше, будучи пенсионерами, и хотели бы работать снова, если бы у них была такая возможность, о причинах прекращения трудовой деятельности. Работающие пенсионеры отвечали на вопросы о мотивах продолжения трудовой деятельности, о возможностях сохранить работу, будучи пенсионерами. Отдельный блок анкеты содержит вопросы об условиях трудовой деятельности пенсионеров (продолжительность рабочего дня, сфера занятости, удовлетворенность условиями труда и т.д.). В анкету включен и общий блок вопросов, на которые отвечали все респонденты: об источниках дохода пенсионеров; о чувствах, которые переживают респонденты (уверенность в будущем, страх перед будущим и т. д.). Анкета также содержит блок вопросов о социально-демографических характеристиках респондентов.

Сбор первичных социологических данных проведен дистанционно посредством программы для онлайн-опросов «Wenjuanxing» с помощью мобильного приложения WeChat.

Математико-статистическая обработка данных опроса проведена с помощью программы IBM SPSS Statistics 26 посредством составления частотных распределений и таблиц сопряжённости с применением критерия непараметрической статистики $\chi^{2}$ Пирсона.

\footnotetext{
1численность населения более 10 миллионов человек.

2Численность населения 5-10 миллионов человек.

ЗЧисленность населения от 1 миллиона до 5 миллионов человек.

4Численность населения от 200 тыс. до 1 миллиона человек.

5численность населения менее 200 тыс. человек.

${ }^{6}$ Включает провинции Ляонин, Хэйлунцзян, Цзилинь.

${ }^{7}$ Включает провинции Шаньдун, Пекин, Шанхай, Хайнань, Хэбэй, Гуандун, Цзянсу, Чжэцзян, Тяньцзинь, Фуцзянь.
} 


\section{Мотивы пенсионеров продолжить трудовую деятельность}

Большинство опрошенных респондентов не работают сейчас и не работали ранее после выхода на пенсию. Так, в настоящее время работают $22 \%$ опрошенных пенсионеров, не работают - $78 \%{ }^{1}$. В рассмотренных регионах доля работающих пенсионеров сопоставима с той, которая получена по стране в целом: в северо-восточном регионе - $24,2 \%$; в восточном - $19 \%$.

Из тех, кто не работает в настоящий момент, ранее работали 30,1 \% опрошенных ${ }^{2}$. В северо-восточном регионе опыт работы на пенсии имели $25,4 \%$ опрошенных, в восточном $-27,1 \%$.

Вместе с тем в ходе исследования выявлена проблема безработицы среди пенсионеров. Согласно определению Международной организации труда (МОТ), безработным считается человек, если он трудоспособен, но не работает, находится в поиске работы и готов к ней приступить достаточно быстро, если появится подходящая вакансия [8]. В соответствии с приведенным определением респондентам были заданы вопросы об их действиях на рынке труда (см. таблицу 1).

Таблица 1

Уровень безработицы среди пенсионеров в Китае (в процентах)

\begin{tabular}{|l|r|r|r|}
\hline \multicolumn{1}{|c|}{ Вопрос } & \multicolumn{1}{|c|}{$\begin{array}{c}\text { По стране в } \\
\text { целом }\end{array}$} & \multicolumn{1}{c|}{$\begin{array}{c}\text { Северо- } \\
\text { восточный } \\
\text { регион }\end{array}$} & $\begin{array}{c}\text { Восточный } \\
\text { регион }\end{array}$ \\
\hline Вы еще намереваетесь работать? & 15,7 & 20,3 & 14,3 \\
\hline $\begin{array}{l}\text { В настоящее время Вы занимаетесь } \\
\text { поиском работы? }\end{array}$ & 9,3 & 13,3 & 10,3 \\
\hline $\begin{array}{l}\text { Если бы у Вас сейчас появилась работа, } \\
\text { Вы смогли бы на нее выйти в течение } \\
\text { двух недель? }\end{array}$ & 19,9 & & 20,8 \\
\hline
\end{tabular}

Установлено, что 15,7 \% респондентов - неработающих пенсионеров - еще намерены работать. Поиском работы занимаются 9,3\% опрошенных. Приступить к работе в течение двух недель, если бы появилась подходящая вакансия, готовы $19,9 \%$ опрошенных. В восточном регионе ситуация напоминает ту, которая сложилась по стране в целом. Уровень безработицы среди пенсионеров в северо-восточном регионе выше.

Представленные данные позволяют заметить, что, во-первых, среди опрошенных существенно преобладают пенсионеры, которые не намерены продолжать трудовую деятельность, не ищут доступные вакансии и не готовы приступить к работе даже при наличии рабочего места. В связи с этим важно определить, что именно мотивирует пенсионеров продолжить трудовую деятельность. Во-вторых, тех, кто намерен работать и готов приступить к работе в течение двух недель, больше, чем тех, кто занимается активным поиском работы. Можем предположить, что существуют барьеры, препятствующие трудовой деятельности пенсионеров.

\footnotetext{
${ }^{1}$ Различия статистически значимые: $\chi^{2} \mathrm{df}=1=125,44 ; \mathrm{p}=0,001$.

2Различия статистически значимые: $\chi^{2} \mathrm{df}=1=49,282 ; \mathrm{p}=0,001$.
} 
Среди мотивов продолжения пенсионерами трудовой деятельности наиболее часто упоминается маленькая пенсия (см. таблицу 2). Подчеркнем, что такой ответ дали, преимущественно, респонденты с пенсией до 2000 юаней $(61,3$ \%) и 20014000 юаней (50 \%). Данную причину не назвали респонденты с пенсией выше 6000 юаней и отметили 9,1 \% респондентов с пенсией 4001-6000 юаней ${ }^{1}$.

Таблица 2

\section{Мотивы продолжения пенсионерами трудовой деятельности (процент наблюдений $)$}

\begin{tabular}{|c|c|c|c|}
\hline Мотив & $\begin{array}{l}\text { По стране в } \\
\text { целом }\end{array}$ & $\begin{array}{l}\text { Северо-восточный } \\
\text { регион }\end{array}$ & $\begin{array}{c}\text { Восточный } \\
\text { регион }\end{array}$ \\
\hline Маленькая пенсия & 47,7 & 57,5 & 70,4 \\
\hline $\begin{array}{l}\text { Желание сделать сбережения } \\
\text { на будущее }\end{array}$ & 55,7 & 60,2 & 60,2 \\
\hline $\begin{array}{l}\text { Стремление материально помочь } \\
\text { детям и/или другим членам } \\
\text { семьи }\end{array}$ & 26,1 & 31,6 & 29,6 \\
\hline Привычка работать & 28,4 & 25,9 & 22,4 \\
\hline Возможность общаться с людьми & 21,6 & 18 & 19,4 \\
\hline Стремление быть полезным & 17 & 15,6 & 12,2 \\
\hline Интерес к выполняемой работе & 26,1 & 23,8 & 23,5 \\
\hline
\end{tabular}

Маленькая пенсия как доминирующий мотив продолжения пенсионерами трудовой деятельности подкрепляется еще одним мотивом. Пенсионеры работают с целью сделать сбережения на будущее. Респонденты отмечают его чаще других или упоминают его вторым по частоте. Доля респондентов, выбравших данный ответ для описания причин продолжения трудовой деятельности, последовательно уменьшается с ростом размера получаемой пенсии. Чаще всего этот ответ выбирают опрошенные с пенсией менее 2000 юаней (71 \%) и от 2001 до 4000 юаней - 52,3%. В свою очередь, мотив сбережений называет каждый третий респондент с пенсией 4001-6000 юаней (36,4 \%). Данный мотив не называют респонденты с пенсией выше 6000 юаней ${ }^{3}$.

Респонденты связывают продолжение трудовой деятельности и с рядом других причин: привычкой работать, возможностью материально поддержать детей и других членов семьи, интересом к выполняемой работе, возможностью общаться с людьми, стремлением быть полезным. Однако можно заметить, что частота упоминания этих мотивов существенно ниже как по стране в целом, так и в исследуемых регионах Китая.

Полученные результаты подтверждаются выводами более ранних исследований китайских ученых. Так, Ван Шусинь описывает четыре категории мотивов занятости пожилых людей: экономические потребности, потребности в работе, наличие опыта и духовная поддержка. В системе мотивов работающих пенсионеров

\footnotetext{
${ }^{1}$ Различия статистически значимые: $\chi^{2} \mathrm{df}=3=10,785 ; \mathrm{p}=0,013$.

${ }^{2}$ Респонденты могли выбрать любое количество ответов.

${ }^{3}$ Различия не достигают уровня статистической значимости: $\chi^{2} \mathrm{df}=3=7,312 ; p=0,062$.
} 
они имеют разную представленность: экономические - 71,23 \%; потребность в работе - 13,25 \%; наличие опыта - 9,33 \%; духовная поддержка - 6,19\%. Можем заметить, что основной причиной трудоустройства пожилых людей в Китае является стремление улучшить материальное положение, нежели стремление к удовлетворению духовных потребностей [9, с. 38-39]. Сделанный вывод согласуется с результатами исследований других авторов [10, с. 24-25].

Таким образом, мотивы продолжения трудовой деятельности у китайских пенсионеров имеют скорее экономический, нежели социальный характер.

\section{Особенности трудовой деятельности работающих пенсионеров: возможность найти и сохранить работу}

Согласно результатам опроса, работающие пенсионеры планируют работать от трех до пяти лет. При этом более 50 \% опрошенных планируют достаточно продолжительную трудовую деятельность на пенсии: от 3-5 до 6-10 лет.

В связи с этим важно рассмотреть, с какими возможностями и ограничениями сталкиваются пенсионеры на рынке труда.

Работающие пенсионеры с оптимизмом оценивают перспективы сохранить рабочее место на тот срок, который они планируют посвятить трудовой деятельности. Так, 78,4 \% респондентов по стране в целом полагают, что им удастся $(38,8$ \%) и скорее удастся $(38,6 \%)$ сохранить работу на планируемый срок ${ }^{1}$. В северо-восточном регионе подобное мнение разделяют $71,8 \%$ респондентов; в восточном $72,4 \%$.

При этом занятость работающих пенсионеров имеет стабильный характер. Почти половине опрошенных работающих пенсионеров $(48,9 \%)$ за последние 5 лет не приходилось менять место работы; еще 25 \% меняли место работы один раз. Вместе с тем 25,1 \% респондентов за последние 5 лет меняли работу более двух раз 2 .

Несмотря на то, что большинство респондентов не меняли место работы, 67 \% искали работу, будучи пенсионерами. При этом большинство столкнулись с рядом проблем (см. таблицу 3).

Чаще других работающие пенсионеры отмечали наличие вакансий с маленькой зарплатой; нежелание работодателей принимать на работу пенсионеров; заключение трудового договора на срок до 1 года; работу без трудового договора.

Иначе выглядит распределение ответов на те же самые вопросы среди неработающих пенсионеров. Так же, как и работающие пенсионеры, среди основных препятствий к трудоустройству они отметили наличие вакансий с маленькой зарплатой и нежелание работодателей принимать на работу пенсионеров. Однако, в отличие от работающих пенсионеров, они почти в три раза чаще отмечали отсутствие вакансий, соответствующих их квалификации.

Таким образом, неработающие пенсионеры мотивированы отказаться от трудоустройства по причине отсутствия вакансий, которые соответствуют квалификации соискателя, и ожидаемой низкой оплаты труда. В свою очередь, работающие пенсионеры имеют негативный опыт низкой оплаты труда и трудоустройства на невыгодных условиях в рамках краткосрочного контракта.

\footnotetext{
${ }^{1}$ Различия статистически значимые: $\chi^{2} \mathrm{df}=3=33,545 ; \mathrm{p}=0,001$.

${ }^{2}$ Различия статистически значимые: $\chi^{2} \mathrm{df}=3=32,818 ; \mathrm{p}=0,001$.
} 


\section{Трудности, с которыми пенсионеры столкнулись при поиске работы (процент наблюдений ${ }^{1}$ )}

\begin{tabular}{|c|c|c|c|c|c|c|}
\hline \multirow[b]{2}{*}{$\begin{array}{l}\text { Трудности при } \\
\text { поиске работы }\end{array}$} & \multicolumn{2}{|c|}{ По стране в целом } & \multicolumn{2}{|c|}{$\begin{array}{c}\text { Северо-восточный } \\
\text { регион }\end{array}$} & \multicolumn{2}{|c|}{ Восточный регион } \\
\hline & $\begin{array}{l}\text { Работаю- } \\
\text { щие пен- } \\
\text { сионеры }\end{array}$ & $\begin{array}{l}\text { Нерабо- } \\
\text { тающие } \\
\text { пенсио- } \\
\text { неры }\end{array}$ & $\begin{array}{l}\text { Работаю- } \\
\text { щие пен- } \\
\text { сионеры }\end{array}$ & $\begin{array}{c}\text { Нерабо- } \\
\text { тающие } \\
\text { пенсио- } \\
\text { неры }\end{array}$ & $\begin{array}{l}\text { Работаю- } \\
\text { щие пен- } \\
\text { сионеры }\end{array}$ & $\begin{array}{l}\text { Нерабо- } \\
\text { тающие } \\
\text { пенсио- } \\
\text { неры }\end{array}$ \\
\hline $\begin{array}{l}\text { Нежелание ра- } \\
\text { ботодателей } \\
\text { брать на работу } \\
\text { пенсионеров }\end{array}$ & 35,3 & 30 & 33,8 & 38,7 & 21,9 & 26,6 \\
\hline $\begin{array}{l}\text { Доступность ва- } \\
\text { кансий с ма- } \\
\text { ленькой зарпла- } \\
\text { той }\end{array}$ & 45,9 & 33,4 & 52,4 & 37,3 & 52,1 & 30,3 \\
\hline $\begin{array}{l}\text { Заключение } \\
\text { временного до- } \\
\text { говора на срок } \\
\text { до } 1 \text { года } \\
\end{array}$ & 18,8 & 5,6 & 10 & 4 & 12,5 & 2,3 \\
\hline $\begin{array}{l}\text { Работа без } \\
\text { оформления } \\
\text { трудового дого- } \\
\text { вора }\end{array}$ & 11,8 & 9,1 & 14,8 & 12 & 12,5 & 8,9 \\
\hline $\begin{array}{l}\text { Нет вакансий, } \\
\text { соответствую- } \\
\text { щих моей про- } \\
\text { фессиональной } \\
\text { квалификации }\end{array}$ & 8,2 & 32,1 & 10 & 25,8 & 9,4 & 33,4 \\
\hline $\begin{array}{l}\text { Не было трудно- } \\
\text { стей }\end{array}$ & 20 & 23,7 & 21 & 19,8 & 21,9 & 27,7 \\
\hline
\end{tabular}

\section{Условия занятости работающих пенсионеров}

Значимость отсутствия вакансий, соответствующих квалификации, в качестве причины незанятости пенсионеров подтверждается распределением ответов на вопросы о занятости до выхода на пенсию и после выхода на пенсию. Так, 75 \% опрошенных по стране в целом отметили, что после выхода на пенсию у них изменилось или место работы (14,8 \%), или профессия $(5,7$ \%), или и то, и другое $(54,5 \%)$. В северо-восточном регионе доля таких респондентов составила 76,2 \%; в восточном $-71,4 \%$.

Сравнение сфер занятости до и после выхода на пенсию позволяет заметить следующие тенденции (см. таблицу 4).

\footnotetext{
${ }^{1}$ Респонденты могли выбрать несколько вариантов ответа.
} 
Сферы занятости респондентов до и после выхода на пенсию (в процентах)

\begin{tabular}{|c|c|c|c|c|c|c|}
\hline \multirow{2}{*}{ Сфера занятости } & \multicolumn{2}{|c|}{ По стране в целом } & \multicolumn{2}{|c|}{$\begin{array}{c}\text { Северо-восточный } \\
\text { регион }\end{array}$} & \multicolumn{2}{|c|}{ Восточный регион } \\
\hline & $\begin{array}{c}\text { До вы- } \\
\text { хода на } \\
\text { пенсию }\end{array}$ & $\begin{array}{c}\text { После вы- } \\
\text { хода на } \\
\text { пенсию } \\
\end{array}$ & $\begin{array}{l}\text { До выхода } \\
\text { на пенсию }\end{array}$ & $\begin{array}{l}\text { После вы- } \\
\text { хода на } \\
\text { пенсию } \\
\end{array}$ & $\begin{array}{l}\text { До выхода } \\
\text { на пенсию }\end{array}$ & $\begin{array}{c}\text { После вы- } \\
\text { хода на } \\
\text { пенсию } \\
\end{array}$ \\
\hline Промышленность & 11,4 & 9,1 & 13,6 & 15,0 & 8,2 & 10,2 \\
\hline Строительство & 2,3 & 1,1 & 2,4 & 1,0 & 2 & 1 \\
\hline Транспорт, связь & 5,7 & 5,7 & 4,4 & 3,7 & 4,1 & 3,1 \\
\hline Сельское хозяйство & 15,9 & 29,5 & 15,6 & 21,8 & 19,4 & 28,6 \\
\hline $\begin{array}{l}\text { Образование, наука, } \\
\text { культура, здраво- } \\
\text { охранение }\end{array}$ & 2,3 & 4,5 & 2,4 & 2,0 & 0 & 0 \\
\hline $\begin{array}{l}\text { Армия, МВД, органы } \\
\text { безопасности } \\
\end{array}$ & 19,3 & 8,0 & 20,1 & 10,9 & 25,5 & 9,2 \\
\hline $\begin{array}{l}\text { Торговля, бытовое } \\
\text { обслуживание, ЖКХ }\end{array}$ & 10,2 & 10,2 & 5,1 & 4,8 & 7,1 & 7,1 \\
\hline $\begin{array}{l}\text { Органы управления, } \\
\text { финансы и страхова- } \\
\text { ние }\end{array}$ & 13,6 & 6,8 & 17,0 & 13,9 & 6,1 & 7,1 \\
\hline Другое & 19,3 & 25,0 & 19,4 & 26,9 & 27,6 & 33,7 \\
\hline
\end{tabular}

Чаще всего после выхода на пенсию респонденты меняли сферу занятости на сельское хозяйство: разница занятых в данной области до и после выхода на пенсию по стране в целом составляет 13,6 процентных пунктов, в восточном регионе - 9,2, в северо-восточном - 6,2. Одновременно наблюдается отток из таких сфер, как силовые структуры (армия, органы безопасности), органы управления, финансы и страхование, промышленность.

Изменение отрасли занятости выглядит закономерным. Наблюдается отток пенсионеров из тех отраслей, которые предъявляют требования к здоровью, а также владению компетенциями, соответствующими уровню развития технологий в финансовой сфере и в области обеспечения безопасности. В свою очередь, максимальный приток наблюдается в сельское хозяйство - в отрасль, которая менее чувствительна к изменениям компетенций сотрудников.

После выхода на пенсию меняется и принадлежность респондентов к категориям работников (см. таблицу 5).

Данные, представленные в таблице, позволяют заметить сокращение количества пенсионеров, занятых на государственных предприятиях. При этом речь идет как о руководящем составе, так и о специалистах, служащих, рабочих. Одновременно наблюдается небольшое увеличение занятых на частных предприятиях. Самый большой прирост наблюдается в категории «индивидуальный предприниматель». Увеличивается количество самозанятых. 
Категории работников, к которым принадлежат респонденты до и после выхода на пенсию (в процентах)

\begin{tabular}{|c|c|c|c|c|c|c|}
\hline \multirow{2}{*}{$\begin{array}{c}\text { Категории } \\
\text { работников }\end{array}$} & \multicolumn{2}{|c|}{ По стране в целом } & \multicolumn{2}{|c|}{$\begin{array}{c}\text { Северо-восточный } \\
\text { регион }\end{array}$} & \multicolumn{2}{|c|}{ Восточный регион } \\
\hline & $\begin{array}{c}\text { До вы- } \\
\text { хода на } \\
\text { пенсию } \\
\end{array}$ & $\begin{array}{c}\text { После вы- } \\
\text { хода на } \\
\text { пенсию } \\
\end{array}$ & $\begin{array}{l}\text { До выхода } \\
\text { на пенсию }\end{array}$ & $\begin{array}{c}\text { После вы- } \\
\text { хода на } \\
\text { пенсию } \\
\end{array}$ & $\begin{array}{l}\text { До выхода } \\
\text { на пенсию }\end{array}$ & $\begin{array}{c}\text { После вы- } \\
\text { хода на } \\
\text { пенсию } \\
\end{array}$ \\
\hline $\begin{array}{l}\text { Государственные слу- } \\
\text { жащие или персонал } \\
\text { государственных } \\
\text { учреждений } \\
\end{array}$ & 13,6 & 6,8 & 15,6 & 13,33 & 4,1 & 4,1 \\
\hline $\begin{array}{l}\text { Работник (специа- } \\
\text { лист, служащий, рабо- } \\
\text { чий) на государствен- } \\
\text { ном предприятии } \\
\end{array}$ & 35,2 & 15,9 & 38,1 & 15,16 & 39,8 & 13,3 \\
\hline \begin{tabular}{|l|} 
Работник (специа- \\
лист, служащий, рабо- \\
чий) на частном \\
предприятии, в орга- \\
низации \\
\end{tabular} & 22,7 & 25,0 & 17,7 & 27,41 & 30,6 & 33,7 \\
\hline $\begin{array}{l}\text { Индивидуальный } \\
\text { предприниматель }\end{array}$ & 3,4 & 14,8 & 10,9 & 17,78 & 7,1 & 16,3 \\
\hline Самозанятый & 25,0 & 33,0 & 17,7 & 26,32 & 18,4 & 24,5 \\
\hline
\end{tabular}

На фоне подобной трансформации структуры занятости пенсионеров в отдельных провинциях Китая появляются программы, направленные на поддержку предпринимательской активности пожилых с целью обеспечения их занятости. В качестве примера может служить «План развития народонаселения провинции Ляонин (2016-2030 годы)» [11].

Рассмотрим условия занятости пенсионеров Китая.

Почти половина работающих пенсионеров по стране в целом оценивает условия труда как очень хорошие $(26,1 \%)$ и хорошие $(20,5 \%)$. Еще 50 \% отмечают наличие как хороших, так и плохих условий. 0 наличие плохих и очень плохих условий труда заявили $3,4 \%$ опрошенных 1 . Схожие данные получены в результате анализа ответов на вопрос «Какие проблемы в первую очередь Вас волнуют по месту работы». Плохие условия труда называют 3,13 \% опрошенных (см. таблицу 6).

Данные, представленные в таблице, позволяют сделать вывод, что на рабочем месте работающие пенсионеры прежде всего обращают внимание на проблемы, связанные с оплатой труда и отсутствием социальных льгот.

${ }^{1}$ Различия статистически значимые: $\chi^{2} \mathrm{df}=4=70,750 ; \mathrm{p}=0,001$. 
Распределение ответов респондентов на вопрос «Какие проблемы в первую очередь Вас волнуют по месту работы?» (процент наблюдений ${ }^{1}$ )

\begin{tabular}{|l|r|r|r|}
\hline \multirow{2}{*}{$\begin{array}{l}\text { Проблема по месту } \\
\text { работы }\end{array}$} & \multicolumn{3}{|c|}{ Доля респондентов, называвших проблему } \\
\cline { 2 - 4 } & По стране в целом & $\begin{array}{c}\text { Cеверо-восточный } \\
\text { регион }\end{array}$ & Восточный регион \\
\hline $\begin{array}{l}\text { Отсутствие социаль- } \\
\text { ных льгот, медицин- } \\
\text { ского обслуживания }\end{array}$ & 37,8 & 38,5 & 41 \\
\hline Низкая оплата труда & 31,3 & 43,1 & 44,9 \\
\hline $\begin{array}{l}\text { Неясность в оплате } \\
\text { труда }\end{array}$ & 29,7 & 30,5 & 30,8 \\
\hline $\begin{array}{l}\text { Опасения потерять ра- } \\
\text { боту }\end{array}$ & 21,6 & 21,3 & 15,4 \\
\hline $\begin{array}{l}\text { Удаленность места ра- } \\
\text { боты от дома }\end{array}$ & 17,6 & 13 & 15,4 \\
\hline $\begin{array}{l}\text { Нет перспектив в про- } \\
\text { фессиональной карь- } \\
\text { ере }\end{array}$ & & & 5,1 \\
\hline $\begin{array}{l}\text { Плохая организация } \\
\text { труда }\end{array}$ & 9,5 & 6,3 & 14,1 \\
\hline $\begin{array}{l}\text { Напряженные отноше- } \\
\text { ния с руководством }\end{array}$ & 8,1 & 12,6 & 6,4 \\
\hline Плохие условия труда & 5,4 & 5 & 5,1 \\
\hline $\begin{array}{l}\text { Плохие отношения в } \\
\text { коллективе }\end{array}$ & 5,4 & 6,7 & 1,3 \\
\hline Работа не нравится & 4,1 & 3,3 & 0 \\
\hline
\end{tabular}

Можем заметить, что выявленные проблемы соотносятся с мотивами продолжения трудовой деятельности пенсионеров. Поскольку основной мотив связан с получением дополнительного дохода, который позволит сделать сбережения и повысить уровень жизни на пенсии, в числе основных проблем на рабочем месте работающие пенсионеры по стране в целом и в исследуемых регионах называют низкую оплату труда и непонятные для них правила ее формирования. Кроме того, респонденты отмечают отсутствие социальных льгот, медицинского обслуживания. При этом социальный аспект трудовых отношений (взаимоотношения с коллегами, с руководством) меньше беспокоит респондентов, чем экономические аспекты занятости.

Работающие пенсионеры подчас высказывают опасение потерять работу. Возможно, именно данное обстоятельство служит причиной негативных эмоциональных переживаний респондентов. Доминирующая эмоция, которую переживают работающие пенсионеры, - уверенность в своем будущем $(55,7 \%)$. В то же время у 35,2 \% работающих пенсионеров присутствует страх перед будущим, 25 \% - ощущают беспомощность и невозможность повлиять на происходящее 2 . Неработающие

\footnotetext{
${ }^{1}$ Респонденты могли выбрать любое количество ответов.

${ }^{2}$ Респонденты могли выбрать любое количество ответов.
} 
пенсионеры чаще испытывают уверенность в своем будущем - 67,3 \%. В то же время они реже испытывают страх перед будущим - 19,6 \% и ощущение неспособности повлиять на происходящее - 19,9\%.

Связи между переживаемыми эмоциями н наличием работы можно объяснить двояко. С одной стороны, страх перед будущим обусловливает необходимость поиска работы. С другой стороны, сама работа может быть источником негативных эмоций. Опасение потерять работу, тревоги, связанные с оплатой труда, прибавляют неуверенности в будущем именно среди работающих пенсионеров.

Таким образом, наличие работы не делает китайских пенсионеров счастливее. Как показал в своем исследовании Лянь Цяньпин на примере опроса пенсионеров в городе Чжуншань (провинция Гуандун, восточный регион), если позволяют экономические условия, большинство пожилых людей надеется, что после выхода на пенсию они смогут заниматься тем, что им интересно, а не продолжать работать $[12$, с. 77].

Вместе с тем работа обеспечивает работающим пенсионерам повышение дохода.

\section{Структура доходов работающих и неработающих пенсионеров}

Согласно результатам опроса, медианный заработок работающих пенсионеров составляет от 2001 до 4000 юаней в месяц. По стране в целом 84 \% опрошенных зарабатывают в месяц до 4000 юаней. В северо-восточном регионе доля получающих такую зарплату составляет $94 \%$; в восточном - 76,8 \%.

При этом 56,8 \% опрошенных работающих пенсионеров по стране в целом отметили, что оплата их труда стала существенно выше $(20,5 \%)$ или немного выше $(36,4$ \%) той, которая была до выхода на пенсию. В то же время 32,9 \% опрошенных заметили незначительное (19,3 \%) и существенное $(13,6$ \%) снижение оплаты труда. Лишь $9 \%$ респондентов считают, что размер оплаты труда не изменился 1 .

Снижение оплаты труда можно объяснить сменой не только места работы, но и профессии, а значит - неизбежной потерей квалификации и как следствие - снижением зарплат. Кроме того, после выхода на пенсию увеличивается количество занятых в сельском хозяйстве - сфере с традиционно более низкой оплатой труда. Наряду с этим снижение размера оплаты труда объясняется оттоком пенсионеров на частные предприятия, где, согласно данным Национального бюро статистики Китая, зарплата ниже, чем на государственных предприятиях [13].

Объяснить повышение оплаты труда после выхода на пенсию сложнее. Возможно, оно связано с расширением предпринимательской деятельности пенсионеров. Вместе с тем нельзя исключать, что пенсионеры, суммируя пенсию и зарплату, субъективно ощущают рост доходов.

Структура доходов работающих пенсионеров включает следующие источники (см. таблицу 7).

\footnotetext{
${ }^{1}$ Различия статистически значимые: $\chi 2 \mathrm{df}=4=17,795 ; \mathrm{p}=0,001$.
} 
Распределение ответов работающих пенсионеров на вопрос «Из каких источников формируются Ваши доходы?» (процент наблюдений ${ }^{1}$ )

\begin{tabular}{|c|c|c|c|c|c|c|}
\hline \multirow[b]{2}{*}{$\begin{array}{l}\text { Источник } \\
\text { дохода }\end{array}$} & \multicolumn{2}{|c|}{ По стране в целом } & \multicolumn{2}{|c|}{$\begin{array}{c}\text { Северо-восточный } \\
\text { регион }\end{array}$} & \multicolumn{2}{|c|}{ Восточный регион } \\
\hline & $\begin{array}{l}\text { Работаю- } \\
\text { щие пен- } \\
\text { сионеры }\end{array}$ & $\begin{array}{c}\text { Нерабо- } \\
\text { тающие } \\
\text { пенсио- } \\
\text { неры }\end{array}$ & $\begin{array}{l}\text { Работаю- } \\
\text { щие пен- } \\
\text { сионеры }\end{array}$ & $\begin{array}{c}\text { Нерабо- } \\
\text { тающие } \\
\text { пенсио- } \\
\text { неры }\end{array}$ & $\begin{array}{l}\text { Работаю- } \\
\text { щие пен- } \\
\text { сионеры }\end{array}$ & $\begin{array}{c}\text { Нерабо- } \\
\text { тающие } \\
\text { пенсио- } \\
\text { неры }\end{array}$ \\
\hline Пенсия & 87,5 & 94,9 & 91 & 98 & 90,7 & 99 \\
\hline $\begin{array}{l}\text { Заработная } \\
\text { плата на основ- } \\
\text { ном месте ра- } \\
\text { боты }\end{array}$ & 44,3 & 2,9 & 31 & 4,3 & 42,3 & 2,9 \\
\hline $\begin{array}{l}\text { Подработка, } \\
\text { совместитель- } \\
\text { ство }\end{array}$ & 20,5 & 1,9 & 22,1 & 3,4 & 22,7 & 1,2 \\
\hline $\begin{array}{l}\text { Помогают род- } \\
\text { ственники }\end{array}$ & 9,1 & 17 & 12,2 & 13,3 & 12,4 & 12,9 \\
\hline $\begin{array}{l}\text { Сдаю в аренду } \\
\text { жилье, иную не- } \\
\text { движимость }\end{array}$ & 2,3 & 7,4 & 3,7 & 2,8 & 4,1 & 1,9 \\
\hline $\begin{array}{l}\text { Получаю про- } \\
\text { центы от сбере- } \\
\text { жений, акций }\end{array}$ & 4,5 & 10,9 & 5,1 & 7,2 & 5,2 & 11,9 \\
\hline $\begin{array}{l}\text { Собственный } \\
\text { бизнес }\end{array}$ & 5,7 & 2,9 & 4,4 & 1,7 & 4,1 & 0,7 \\
\hline
\end{tabular}

Можно заметить, что структура доходов у двух категорий респондентов отличается. Так, основные источники дохода работающих пенсионеров представлены пенсией и зарплатой по основному месту работы или совместительству. В свою очередь, основные источники дохода неработающих пенсионеров - пенсия и проценты от сбережений, акций.

Связь структуры доходов и статуса пенсионера можно трактовать двояко. С одной стороны, отсутствие других доходов, кроме пенсии, мотивирует пенсионеров продолжить трудовую деятельность. С другой стороны, возможность жить на сбережения или получать помощь от родственников позволяет пенсионерам не работать.

\section{Выводы и рекомендации}

Рассмотренные характеристики структуры занятости пенсионеров Китая позволяют сделать следующие выводы.

Уровень занятости китайских пенсионеров невысок. При этом если рассмотреть ситуацию в динамике, то можем прийти к заключению, что занятость пенсионеров снижается. Так, согласно результатам пятой и шестой национальных переписей населения Китая 2015 года, уровень занятости пожилых людей старше 60 лет

\footnotetext{
${ }^{1}$ Респонденты могли выбрать любое количество ответов
} 
снизился с 28,56 \% в 1990-е годы до 26,83 \% в 2015 году [14, с. 120]. По результатам проведенного исследования данная цифра еще более уменьшилась. Отмеченная тенденция не отвечает целям социально-экономического развития государства на фоне стремительного старения населения Китая и растущей демографической нагрузки на трудоспособное население.

Работающие пенсионеры вынуждены менять место работы. Согласно полученным результатам, чаще всего в качестве «принимающей» отрасли выступает сельское хозяйство, обрабатывающая промышленность, строительство, сфера обслуживания. Однако, как подчеркивают эксперты, чаще всего пенсионеры заняты низкоквалифицированным трудом [Там же]. Можно предположить, что основная причина состоит в отсутствии у большинства пенсионеров образования, которое соответствовало бы уровню технологического развития одной из ведущих экономик мира. В результате возникает проблема не только количественных показателей занятости пенсионеров в Китае, но и качества занятости.

В связи с этим повышение пенсионного возраста должно сопровождаться разработкой мер содействия занятости пожилых с учетом как количественных, так и качественных аспектов.

Анализ содержания барьеров занятости, названных респондентами, позволяет предложить следующие меры, которые могли бы содействовать занятости пенсионеров.

Отмечаемое и работающими, и неработающими пенсионерами нежелание работодателей брать на работу пожилых может быть преодолено посредством государственных программ, которые поощряли бы работодателей создавать рабочие места для пенсионеров. Фактически речь идет о политике «субсидирования» занятости для пожилых людей.

Кроме того, важно инвестировать соответствующие средства в создание системы службы занятости, чтобы обеспечить более широкие каналы для трудоустройства пожилых.

Анализ незанятости пенсионеров позволил сделать вывод, что данный феномен связан, в том числе, и с отсутствием должного образования у респондентов. Так, пенсионеры без высшего образования чаще других обращают внимание на нежелание работодателей принимать на работу пенсионеров. Респонденты с высшим образованием отмечали отсутствие вакансий, соответствующих их квалификации. Описанные тенденции могут быть разными проявлениями одной и той же проблемы. У пенсионеров без высшего образования возникают трудности с поиском работы, поскольку они не обладают должным уровнем квалификации в условиях современного уровня развития экономики. Респонденты с высшим образованием, которые вправе рассчитывать на вакансии, соответствующие их квалификации, тем не менее не получают их, поскольку их компетенции уже не соответствуют требованиям рынка труда. В связи с этим в условиях ожидаемого в Китае повышения пенсионного возраста более поздний выход на пенсию необходимо сопровождать введением программ профессионального обучения и профессиональной переподготовки для граждан пенсионного и предпенсионного возраста.

Правительство Китая осознает важность решения проблемы образования пожилых. Так, в «Плане образования взрослых на 2016-2020 годы» поставлена цель иметь, по меньшей мере, один университет для пожилых в каждом городе и создать в 30 \% поселков учебные центры для пожилых [15, с. 9]. 
Нельзя не отметить, что желание пенсионеров продолжить трудовую деятельность имеет выраженные экономические мотивы. В связи с этим требуется система мер, которые сделали бы трудовую деятельность экономически выгодной для пожилых.

\section{Ссылки / References}

1. World Population Prospects 2019. Highlights. New York, 2019. 39 p. // United Nations. Department of Economic and Social Affairs. URL: https://population.un.org/wpp/Publications/Files/WPP2019_Highlights.pdf (дата обращения: 27.07.2021).

2. Ke Meng. China's Pension Reforms. Political Institutions, Skill Formation and Pension Policy in China. London, NY: Routledge Taylor \& Francis Group, 2019. 253 p.

3. Henry C., Fraga F., Tang Yu What drives old age work in China? // International Labor Office, Research Department. Working Paper. № 40. December 2018.

URL: https://www.ilo.org/wcmsp5/groups/public/---dgreports/--inst/documents/publication/wcms_659543.pdf (дата обращения: 01.08.2021).

4. Цзинтин В. Система пенсионного обеспечения в Китае: взгляд эконом-социолога // Социология и право. 2019. № 3. С. 47-53.

5. В Китае объявили о повышении пенсионного возраста // РИА Новости. 05.03.2021. URL: https://ria.ru/20210305/kitay-1600032876.html (дата обращения: 29.07.2021).

6. Идеальное общество в мечтах людей в России и в Китае: [монография] / [М. К. Горшков и др.]; отв. ред. М. К. Горшков, П. М. Козырева, Ли Пэйлинь, Н. Е. Тихонова. М.: Новый хронограф, 2016. 424 с.

7. Отчет об исследовании «Последующее социальное обследование пожилых людей в Китае» // Институт исследований пожилых людей Китайского народного университета (на кит. языке). URL: http://class.ruc.edu.cn/_local/A/C8/C1/E7CD54DD4D41F4BD6DE281043FD_10F38E30_1A 56C5.pdf?e=.pdf (дата обращения: 13.01.2021).

8. Понятия и определения // Федеральная служба государственной статистики. URL: https://gks.ru/bgd/regl/b08_30/isswww.exe/stg/d020/vved-5.htm (дата обращения: 27.07.2021).

9. Ван Шусинь. Анализ занятости населения старшего Китая // Население и экономика. 1990. № 3. С. 35-39 (на кит. языке).

10. Ц Цянь Синь, Цзян Сянцюнь. Анализ факторов, влияющих на стремление пожилых людей к трудоустройству в городе Китая // Журнал народонаселения. 2006. № 5. С. 24-29 (на кит. языке).

11. Уведомление народного правительства провинции Ляонин о печати и распространении плана развития населения провинции Ляонин (2016-2030 гг.) // Документы народного правительства провинции Ляонин. 2018. № 20 (на кит. языке). URL: http://www.ln.gov.cn/zfxx/zfwj/szfwj/zfwj2011_125195/201807/t20180703_3273280. html (дата обращения: 25.05.2021). 
12. Лянь Цяньпин. Эмпирический анализ готовности пожилых людей к повторному трудоустройству в контексте демографического дивиденда пожилых людей // Вестник института Сючан. 2018. № 7. С. 76-78 (на кит. языке).

13. Средняя годовая заработная плата работников городских частных предприятий в 2019 году составила 53604 юаня // Национальное бюро статистики (на кит. языке). URL: http://www.stats.gov.cn/tjsj/zxfb/202005/t20200515_1745763.html (дата обращения 15.05.2021).

14. Лю Бинь, Гао Инбо. Исследование развития человеческих ресурсов пожилых людей на фоне старения населения // Современная экономика. 2020. № 8. С. 119-122 (на кит. языке).

15. Inclusive Future of Work The People's Republic of China Country brief prepared for the 1st EWG under the 2019 Brazilian presidency of the BRICS // International Labour Organization. URL: https://www.ilo.org/wcmsp5/groups/public/---dgreports/--cabinet/documents/publication/wcms_732870.pdf (дата обращения: 02.08.2021). 